\title{
What We Know and Don't Know about Manager Responses: A Review and Synthesis of the Literature
}

\author{
Zhaoxu Fang \\ School of Management, Jinan University, Guangzhou, China \\ Email: fangzhaoxu71@126.com
}

How to cite this paper: Fang, Z. X. (2020). What We Know and Don't Know about Manager Responses: A Review and Synthesis of the Literature. Open Journal of Social Sciences, 8, 11-24.

https://doi.org/10.4236/jss.2020.85002

Received: April 10, 2020

Accepted: May 5, 2020

Published: May 8, 2020

Copyright $\odot 2020$ by author(s) and Scientific Research Publishing Inc. This work is licensed under the Creative Commons Attribution International License (CC BY 4.0).

http://creativecommons.org/licenses/by/4.0/

\section{(c) (i) Open Access}

\begin{abstract}
In the past few years, a large number of scholars have paid attention to manager responses. Although the existing research has helped us to have a good understanding of some problems related to manager responses, there are still some academical and management problems. Moreover, no attempt has been made to consolidate and synthesize research in this area. As consumers increasingly rely on online retail, hotel reservation and information search, and the continuous growth of social media, the importance of manager response cannot be overemphasized. Based on a systematic review of several studies, we have made a comprehensive analysis of the manager responses in multiple dimensions, and raised the current and ongoing research key issues. Companies respond to different types of reviews (for different types of reviews, different platforms and different response strategies), which may have different effects (three aspects of platforms, hotels and consumers), which can be explained by attribution theory, social learning theory and others. The future research should further explore whether there are other key influencing factors in the review response, and try to analyze the reasons why different factors have different influence from a new theoretical perspective.
\end{abstract}

\section{Keywords}

Online Reviews, Manager Response, Systematic Review, c2c Interactions, Social Influences

\section{Introduction}

In the era of Information, customers have more and more channels interacting with companies. Customers can not only reflect their positive or negative experience of shopping by commenting on e-commerce platform (like Taobao, 
JDcom etc.), but also comment about the content publishing on companies' official micro blog. Moreover, customers can discuss with other customers or companies about product design or experience and give their suggestions in the brand community. For example, according to the data collected by Wang and Chaudhry (2018), it is found that on the top three tourism websites (TripAdvisor, Expedia, hotels. Com), the proportion of hotel managers responding to reviews has gradually increased, and TripAdvisor's response is the most positive. In 2015, nearly 52\% of reviews were responded, and Expedia's response to reviews increased significantly in 2014 and 2015, from the previous $8 \%$ to nearly all reviews $25 \%$ of the total, hotels.com lagged slightly in the ability to respond to reviews, up from $18.1 \%$ in 2015.

As the interacting channels increasing, customers have more freedom publishing their reviews about brands and productions, no matter positive or negative, on different platforms. Various marketing researches have verified the impact of online reviews on product sales (Chevalier \& Mayzlin, 2006; Godes \& Mayzlin, 2004, 2009; Zhu, 2010), customer satisfaction (Forman et al., 2008), and stock prices (Tirunillai \& Tellis, 2012). With the huge communication efficiency of the Internet, companies are urged to closely monitor and manage online reviews.

Previous researches have found that positive reviews have a positive impact on product sales and evaluation (East et al., 2008), and for brands that consumers are using, the effect of positive word-of-mouth on improving purchase intention is greater than that of negative word-of-mouth (East et al., 2017). Corresponding previous studies have found many negative effects of negative reviews, which is a serious threat to marketers (Hennig-Thurau et al., 2010), because negative reviews have potential hazards, which will damage consumers' company attitudes (Purnawirawan et al., 2015), purchase intention (Lee \& Youn, 2009), product trial (Huang \& Korfiatis, 2015), product sales (Cui et al., 2012) and ultimately affect the image of the company in the market (Lee \& Youn, 2009). In addition, Kim et al. (2016) also found that negative comments have a negative impact not only on the reviewers who post the comments but also on the viewers/bystanders.

In the face of these threats of negative comments, enterprises must find ways to control these adverse effects. This method is review response. Previous studies have found that review response can effectively alleviate the negative impact of negative reviews from consumers (Sreejesh \& Anusree, 2016; van Noort \& Willemsen, 2012; Weitzl et al., 2018). As the manager responses is a new concept, the research on it is still in its infancy. The first concern of relevant research is the effect of manager responses, that is, whether manager responses can bring significant impact on companies. After that, most scholars turn to study the different effects of different types of manager responses. There are two types of manager responses that are classified according to the way of companies' responses: defensive responses and accommodative responses (Lee \& Song, 2010), and previous researchers have found that different platforms (Platform Type 
Brand-generated vs. Consumer-generated) (Schamari \& Schaefers, 2015; van Noort \& Willemsen, 2012). Some researchers also found classification according to the type of review (severity of company error explained in the review) (Tathagata \& Amar, 2018; Weitzl et al., 2018).

Through the literature review, it is found that most of the researches are based on the attribution theory to explain how the manger responses alleviates the negative impact of the negative review (Kim et al., 2016; Lee \& Song, 2010; Li, 2018; Weitzl et al., 2018), or to explain with the reinforcement theory and social learning theory (Schamari \& Schaefers, 2015; Weitzl \& Hutzinger, 2017). It can be found that the theoretical basis of related fields is relatively weak.

In addition, it is worth noting that in the previous studies, most of the results about the impact of manger responses focused on the evaluation, attitude and loyalty of consumers to brands (Ghosh, 2017; Lee \& Song, 2010; Tathagata \& Amar, 2018; van Noort \& Willemsen, 2012; Weitzl \& Hutzinger, 2017), and a few scholars are concerned about the willingness of review observers to participate in the review (Schamari \& Schaefers, 2015) or the future purchase intention (Kim et al., 2016).

Based on the above review of manger responses, At the practical level, more relevant research is expected to help companies formulate appropriate review response strategies, while at the theoretical level, there are many research gaps worthy of attention for scholars to explore. So this paper will discuss the previous research on review responses from three key points: the strategy of manger responses, the influence of manger responses and the theoretical explanation of manger responses.

\section{The Concept and Classification of Manger Responses}

Nowadays consumers have more and more opportunities to tell their complaints to the public, which leads to great challenges for companies (Hennig-Thurau et al., 2010). Because the existence of negative reviews may have a negative impact on a large number of potential consumers, and have a great impact on consumers' brand perception, choice and loyalty (Chevalier \& Mayzlin, 2006; Sen \& Lerman, 2007; Vermeulen \& Seegers, 2009), companies need to detect and intervene it, so they can control the potential harm (Malthouse, 2007). These behaviors of monitoring and intervening online complaints carried out by companies are called "WEBCARE" (Weitzl \& Hutzinger, 2017). Van Noort and Willemsen (2012) first gave an accurate definition of "the behaviors of responding to consumers' feedback (such as questions, concerns and complaints) through active search network, and interacting with (complaining) consumers online".

In addition to "WEBCARE", there is also the management response, also known as manager responses, which is also a concept on review response. Wang and Chaudhry (2018) defined it as "the behavior of managers responding to online reviews publicly". Many researchers rely on experiments to demonstrate the impact of management response on consumers' attitude (Lee \& Cranage, 2014), 
satisfaction (Min et al., 2015), trust (Sparks, So, \& Bradley, 2016) and the evaluation of companies (Crijns et al., 2017; Lee \& Cranage, 2014). This concept is mostly based on the background of hotel reviews. Most of them are about the hotel mangers' response to reviews. Compared with the concept of "WEBCARE" which is just for negative reviews, manger responses are applicable to both positive and negative reviews, which is quite suitable for the situation of this paper. Therefore, this paper adopts the concept of manger responses.

After describing the basic concept of manger responses, it is more important to understand how predecessors classified manger responses. Because the manger response contains several key influencing factors which carry the platform of manger response, the subject and object of responses. So next, this paper summarizes the previous researches and discusses the classification of manger response according to the type of response platform, the way of response and the type of response.

\subsection{Platform Type of Manger Response}

Generally, the types of response platforms can be divided into social platforms and shopping platforms, manger responses of companies will have different impacts on different platforms. Shopping platforms mainly refer to hotels. Many scholars have conducted a lot of research on Hotels' manger responses (Chevalier et al., 2018; Li, 2018; Wang \& Chaudhry, 2018; Yan \& Wang, 2018). Other scholars have conducted research on social networking sites like Facebook (Johnen \& Schnittka, 2019; Schamari \& Schaefers, 2015; Sheng, 2019).

In addition to this classification, Schamari and Schaefers (2015) also classify platform types into consumer generation platform and brand generation platform, based on social learning theory they propose manger response as a reaction to positive engagement to be an effective marketing tool for reinforcing observing consumers' engagement intentions, especially on consumer-generated platforms.

\subsection{Reviews Type of Manger Response}

According to the general review classification, the types of manger responses can be divided into negative reviews responses and responses on positive reviews. Most of the existing researches focus on the negative review response, because negative review can give consumers more influence on purchase intention than positive review (East et al., 2017). For the research of negative manger responses, from the beginning of exploring the usefulness of manger responses (Lee \& Song, 2010), it has gradually developed to study the impact of negative review classification on responses. These classifications mainly include: the impact of the consistency of negative reviews (Lee \& Cranage, 2014; Lee \& Song, 2010); the impact of the degree of negative reviews' service failure (Chang et al., 2015; Li, 2018), the impact of the vividness of reviews (Lee \& Song, 2010); the impact of the type of observers (viewer vs. poster) (Kim et al., 2016); whether the rating of negative 
reviews is very low (Gu \& Ye, 2014); volume and variance of negative reviews (Xie et al., 2014), etc.

In the researches of positive manger responses, only the step of whether positive manger responses have effect was carried out (Schamari \& Schaefers, 2015), and whether the tailored positive responses have negative influence on reviews observers (Wang \& Chaudhry, 2018).

\subsection{The Type of Response Strategy}

The most important part in the research of manger responses are what kind of response strategy the companies use. Therefore, different scholars give different response strategies for different review valence.

First for negative reviews, brand response strategies encompass two main categories: accommodative or defensive (Marcus \& Goodman, 1991). This distinction is based on whether the brand does or does not acknowledge responsibility for the complaint (Kim et al., 2004). Accommodative responses signal that the brand accepts responsibility by including an apology, compensation, corrective actions, helpful information, or regret (Davidow, 2003). Defensive responses reject responsibility and include indicators such as denial, doubts, excuses, trivializing, or accusations (Conlon \& Murray, 1996; Marcus \& Goodman, 1991).

Many literatures have explored these two types of responses (Chang et al., 2015; Johnen \& Schnittka, 2019; Lee \& Cranage, 2014; Lee \& Song, 2010; Li, 2018), basically all the researches consider the accommodative responses to be better than the defensive responses, because generally speaking, the accommodative response is better than the defensive response strategy to stimulate favorable consumer results, such as better brand evaluation or purchase intention. But in the research of Johnen and Schnittka (2019), it was found that defensive response may have better effect in the case of hedonic products, but it will decrease in the case of practical products.

In addition to the classification of accommodative and defensive, previous scholars also based on the voice of reviews (impersonal vs. personal) (Schamari \& Schaefers, 2015), professional voice or conversational human voice (Sparks et al., 2016), tone of voice organizational response (personalized vs. corporate) (Crijns et al., 2017), the type of brand communication (formal vs. informal) (Johnen \& Schnittka, 2019). All of these can be attributed to the same type, i.e. anthropomorphic mood and nonanthropomorphic mood.

There are other related categories of negative manger responses, such as the speed of responses, which have been proved to have no significant impact on consumer satisfaction in the consumer platform (Min et al., 2015), while have an great impact on consumers in the social platform (Johnen \& Schnittka, 2019). Whether the response contains empathy and whether the response contains the content of the review have a significant impact on consumer satisfaction (Min et al., 2015), but the framework of manger responses (past action or future access) has no significant impact on consumer preference (Sparks et al., 2016). 
Finally, the credibility of the response (Weitzl \& Hutzinger, 2017), the source of the response (brand itself vs. brand advocates) (Weitzl \& Hutzinger, 2017), the situation of benefit (hedonic vs utilitarian) (Johnen \& Schnittka, 2019), and the response volume (Sheng, 2019), also have a significant impact on consumers.

The response classification for positive reviews is less, only Schamari and Schaefers (2015) found that the response effect of positive reviews on the consumer generation platform is better, and Wang and Chaudhry (2018) found that the higher the similarity between the response and the review, the lower the consumer's hotel rating.

\section{The Impact of Manger Response}

According to the above three important components of manger response (platform, subject and object of responses), this research discusses the impact of manger responses from three aspects: the impact on consumers, the impact on websites, and the impact on companies.

For the consumers, because the main viewer of the manger response is still other consumers who browsing the review area, the main influence object of manger response is also other consumers who browsing reviews (review observers). Therefore, most of the previous researches focused on the impact of responses on review observers. Among these impact researches, Lee and Song (2010) found that more observers think that negative reviews are consensus and vivid, the more they think that companies make mistakes and give negative reviews, and many scholars also regard the attitude towards brand or company as a dependent variable (Ma et al., 2015; Rose \& Blodgett, 2016; van Laer et al., 2013; van Noort \& Willemsen, 2012; Wei et al., 2013; Weitzl \& Hutzinger, 2017).

The main impact of website reviews is that it will have an impact on the willingness of other consumers to post reviews in the future. Schamari and Schaefers (2015) found that the personal voice response of companies in the consumer generation platform can enhance the willingness of consumers to participate in reviews; the corresponding Sheng (2019) also found the elements of responses (response volume|, response Length, response speed) has an impact on consumer participation in reviews. In addition to the above two articles, many other scholars have also found the impact of responses on the number of reviews (Li et al., 2017; Proserpio \& Zervas, 2017). In addition to the volume of reviews, consumers' ratings are also affected. Although some scholars have found that responses have no significant impact on the subsequent scores of review posters or review viewers (Gu \& Ye, 2014), but some scholars also found that the responses can significantly affect the next rating of review viewers (both positive and negative review responses have a significant impact) (Wang \& Chaudhry, 2018), and a large number of scholars have similar findings that the significantly affect of responses on consumers' rating (Chevalier et al., 2018; Li et al., 2017; Proserpio \& Zervas, 2017). Other influences include voting on the usefulness of reviews, higher popularity ranking of hotels (Li et al., 2017), and length of following re- 
views (Chevalier et al., 2018).

The impact of manger response on the hotel is mainly reflected in the purchase intention of consumers, for example, some found different response strategies will affect the purchase intention of potential consumers (Mauri \& Minazzi, 2013); others found the response of negative reviews can increase hotel revenue per available room (Xie et al., 2014) and the future purchase intention of posters and viewers (Kim et al., 2016). Li (2018) also found that different responses strategies to different negative reviews would have an impact on the purchase intention of potential consumers.

\section{The Mechanism of Manger Response's Effect}

As the previous research focuses on the response of negative reviews, so most of the theories used are to alleviate the negative attitude of consumers, such as attribution theory. There are other theories like reinforcement theories and social learning theories that can bring positive effects to companies.

\subsection{Attribution Theory}

According to "attribution theory" individuals tend to formulate logical and well-reasoned accounts for incidents and behaviors they wish to understand. These causal inferences have important effects on individuals' subsequent reactions (Bandura \& Walters, 1977; Kelley \& Michela, 1980). Applied to the service failure context, "failure attributions" are defined as the causes inferred by complainants of why the service problem actually occurred (Weitzl et al., 2018). The most common categorization of attributions used to study service failures stems from Weiner (1979), who identifies three independent dimensions: attribution of locus, attribution of controllability, and attribution of stability.

Attribution of locus refers to who or what the service failure should be attributed to. If the complainants attribute the problem to themselves ("internal attribution"), it is called low locus; when the problem is attributed to the company or brand (i.e. "external attribution"), it is called high locus (Weitzl et al., 2018).

Attribution of controllability refers to the complainant's inference about whether the company can avoid the problem (Browning et al., 2013). When consumers attribute service failure to uncontrollable and unforeseeable reasons, they will not associate it with the company's voluntary or negligent behaviors, but with situations beyond the company's control. However, when consumers perceive (high) controllability, they may try to punish the company for failing to protect customers from controllable failures (such as foreseeable problems) by switching suppliers or participating in NWOM (Folkes et al., 1987).

Finally, attribution of stability refers to the fact that the complainant believes that the cause of service failure is temporary (changing with time) or relatively permanent (Browning et al., 2013). If the complainant attributes the failure to stability, the possibility of dissatisfaction will increase in the future, and then 
whose friends and acquaintances will be reminded not to buy anything from related companies or brands (Browning et al., 2013).

Relevant researches have found that when consumers agree with negative reviews, companies' response to external attribution (defensive response) is more able to change consumers' negative attitude than that to internal attribution (Lee \& Cranage, 2014). Weitzl and Hutzinger (2017) found that negative reviews' response has considerable potential to reduce the failure attribution disliked by the complainants, which may lead to behaviors adverse to the company or the brand (for example, expressing criticism to colleagues). However, the impact depends on whether the complainant has a perspective entity in the past.

\subsection{Empathy Theory, Social Learning Theory and Others}

Empathy is considered to be an important factor in understanding consumers and meeting their needs (Drollinger et al., 2006). Lack of empathy among employees can cause a high number of customer complaints. Therefore, empathy is considered a key component in responding to customer complaints (Min et al., 2015). Scholars found that negative review responses with empathy content were more likely to attract potential customers (Min et al., 2015).

Consumers learn not only from direct experience, but also by observing them and imitating the behavior of others (Schamari \& Schaefers, 2015). Therefore, when consumers observe the dialogue between the review poster and the company, they learn that the company is trying to solve the problems encountered by consumers. Viewers may think that the company's response has a higher complaint utility because of its obvious identity and expertise (Breitsohl et al., 2010). Therefore, the positive effect of negative review responses on viewers is higher than that of posters (Kim et al., 2016).

Other theories include the social comparison theory and prospect theory which introduced by Weitzl and Hutzinger (2017); and the cognitive dissonance theory and emotional sharing theory is introducing by Kim et al. (2016); finally the psychological resistance theory and indirect reciprocity theory is introducing by Yan and Wang (2018) and Wang and Chaudhry (2018).

\section{Future Direction}

Based on the above three aspects, this paper finds that although predecessors have made a lot of contributions in the research field of manger responses, there are still some research gaps worthy of further exploration by later researchers.

\subsection{The Future of Manger Response Classification}

The first point: researches on the valence of reviews in manger responses. Previous researches have focused on negative reviews (Johnen \& Schnittka, 2019; Lee \& Cranage, 2014; Lee \& Song, 2010; Ma et al., 2015; Mauri \& Minazzi, 2013; Sheng, 2019; Xie et al., 2014), but few have focused on positive reviews. In the future, more scholars are expected to study the positive review response, for 
example, the impact of the positive review type on the manger response, or the different impact of the frequency, speed, content length and other factors of the positive manger response on consumers.

The second point: the research of review content in manger response. Previous studies have classified the review content according to the severity of failure (Chang et al., 2015; Li, 2018), consistency (Lee \& Cranage, 2014; Lee \& Song, 2010), vividness (Lee \& Song, 2010), length, and the number of empathic information (Min et al., 2015), and then studied the impact of different review elements on the response. However, according to the analysis of the practice, the review content itself contains a lot of elements, such as the emotional, factual, time proximity and other elements can be further explored.

The third point: the type of manger response. In previous studies, the types of response to reviews were roughly divided into defensive response and accommodative response (Chang et al., 2015; Johnen \& Schnittka, 2019; Lee \& Cranage, 2014; Lee \& Song, 2010; Li, 2018); formal response, informal response; personal response, impersonal response (Schamari \& Schaefers, 2015); manager's response, general employee's response (Sparks et al., 2016); internal response, response from other consumers; or classification based on the speed and length of manger response. Although the classification of these responses can summarize most of the real scenes, there are still new situations such as whether the manger response is hidden, whether the manger response only displays the rest of the first two lines and so on. In view of these new situations, we also hope to explore the different effects on consumers.

\subsection{The Future Explore of Theoretical Explanation}

Due to the strong practical significance of the research related to manger response, many impacts or effects can be explained in clear language, or verified with rigorous models and a large number of data. As a result, the theoretical basis of research in related fields is relatively weak. The most widely used theory in the research of negative manger response is attribution theory (Weitzl et al., 2018), because attribution theory can explain how manger response can alleviate the negative impact of negative comment on consumers (Lee \& Song, 2010), and why consumers see different review types will have different attitudes towards companies. The corresponding social learning theory has also been applied in related fields, because social learning theory can explain the phenomenon that consumers participate in reviews more after observing reviews (Schamari \& Schaefers, 2015). In the future research, more scholars should explore the theoretical explanation behind the various effects of manger responses, such as fluency processing theory and psychological resistance theory.

First, future researches can use the theory of fluency processing theory to explore the internal mechanism of manger response affecting consumers. In general, the theory distinguishes two modes of information processing: fluent processing, which is largely holistic and occurs without much deliberate reasoning, 
and less-fluent processing, which is rather step-by-step and deliberate (Joško Brakus et al., 2014). After observing the manger response of the positive reviews, consumers get a lot of positive information about the hotel. Because of the theory of fluency processing, consumers will be more inclined to process as a whole, so they will transfer their preference for manger response to the preference for companies or brands.

Second, future researches can explore the negative impact of manger response on consumers through the theory of psychological resistance. When an individual's autonomy or freedom is deprived or threatened, psychological resistance will occur (Brehm, 1966). Previous researches have explained the influence of psychological resistance on consumers' attitude towards marketing information, and found that consumers are more distrustful and dislike to perceive advertisements with obvious guiding intention, and are more reluctant to buy the products they publicize (Robertson \& Rossiter, 1974). Therefore, when consumers browse the positive manger response, the company's propaganda information and advertisement contained in it may cause psychological resistance of consumers. So it can explain why the positive comments will reduce the consumers' evaluation of the enterprise.

\section{Conflicts of Interest}

The authors declare no conflicts of interest regarding the publication of this paper.

\section{References}

Bandura, A., \& Walters, R. H. (1977). Social Learning Theory(Vol. 1). Englewood Cliffs, NJ: Prentice-Hall.

Brehm, J. W. (1966). A Theory of Psychological Reactance.

Breitsohl, J., Khammash, M., \& Griffiths, G. (2010). E-Business Complaint Management: Perceptions and Perspectives of Online Credibility. Journal of Enterprise Information Management, 23, 653-660. https://doi.org/10.1108/17410391011083083

Browning, V., So, K. K. F., \& Sparks, B. (2013). The Influence of Online Reviews on Consumers' Attributions of Service Quality and Control for Service Standards in Hotels. Journal of Travel \& Tourism Marketing, 30, 23-40. https://doi.org/10.1080/10548408.2013.750971

Chang, H. H., Tsai, Y. C., Wong, K. H., Wang, J. W., \& Cho, F. J. (2015). The Effects of Response Strategies and Severity of Failure on Consumer Attribution with Regard to Negative Word-of-Mouth. Decision Support Systems, 71, 48-61. https://doi.org/10.1016/j.dss.2015.01.007

Chevalier, J. A., \& Mayzlin, D. (2006). The Effect of Word of Mouth on Sales: Online Book Reviews. Journal of Marketing Research, 43, 345-354. https://doi.org/10.1509/jmkr.43.3.345

Chevalier, J. A., Dover, Y., \& Mayzlin, D. (2018). Channels of Impact: User Reviews When Quality Is Dynamic and Managers Respond. Marketing Science, 37, 688-709. https://doi.org/10.1287/mksc.2018.1090

Conlon, D. E., \& Murray, N. M. (1996). Customer Perceptions of Corporate Responses to 
Product Complaints: The Role of Explanations. Academy of Management Journal, 39, 1040-1056. https://doi.org/10.2307/256723

Crijns, H., Cauberghe, V., Hudders, L., \& Claeys, A. S. (2017). How to Deal with Online Consumer Comments during a Crisis? The Impact of Personalized Organizational Responses on Organizational Reputation. Computers in Human Behavior, 75, 619-631. https://doi.org/10.1016/j.chb.2017.05.046

Cui, G., Lui, H. K., \& Guo, X. (2012). The Effect of Online Consumer Reviews on New Product Sales. International Journal of Electronic Commerce, 17, 39-58. https://doi.org/10.2753/JEC1086-4415170102

Davidow, M. (2003). Organizational Responses to Customer Complaints: What Works and What Doesn't. Journal of Service Research, 5, 225-250. https://doi.org/10.1177/1094670502238917

Drollinger, T., Comer, L. B., \& Warrington, P. T. (2006). Development and Validation of the Active Empathetic Listening Scale. Psychology \& Marketing, 23, 161-180. https://doi.org/10.1002/mar.20105

East, R., Hammond, K., \& Lomax, W. (2008). Measuring the Impact of Positive and Negative Word of Mouth on Brand Purchase Probability. International Journal of Research in Marketing, 25, 215-224. https://doi.org/10.1016/j.ijresmar.2008.04.001

East, R., Romaniuk, J., Chawdhary, R., \& Uncles, M. (2017). The Impact of Word of Mouth on Intention to Purchase Currently Used and other Brands. International Journal of Market Research, 59, 321-334. https://doi.org/10.2501/IJMR-2017-026

Folkes, V. S., Koletsky, S., \& Graham, J. L. (1987). A Field Study of Causal Inferences and Consumer Reaction: The View from the Airport. Journal of Consumer Research, 13, 534-539. https://doi.org/10.1086/209086

Forman, C., Ghose, A., \& Wiesenfeld, B. (2008). Examining the Relationship Between Reviews and Sales: The Role of Reviewer Identity Disclosure in Electronic Markets. Information Systems Research, 19, 291-313. https://doi.org/10.1287/isre.1080.0193

Ghosh, T. (2017). Managing Negative Reviews: The Persuasive Role of Webcare Characteristics. Journal of Internet Commerce, 16, 148-173. https://doi.org/10.1080/15332861.2017.1305254

Godes, D., \& Mayzlin, D. (2004). Using Online Conversations to Study Word-of-Mouth Communication. Marketing Science, 23, 545-560. https://doi.org/10.1287/mksc.1040.0071

Godes, D., \& Mayzlin, D. (2009). Firm-Created Word-of-Mouth Communication: Evidence from a Field Test. Marketing Science, 28, 721-739. https://doi.org/10.1287/mksc.1080.0444

Gu, B., \& Ye, Q. (2014). First Step in Social Media: Measuring the Influence of Online Management Responses on Customer Satisfaction. Production and Operations Management, 23, 570-582. https://doi.org/10.1111/poms.12043

Hennig-Thurau, T., Malthouse, E. C., Friege, C., Gensler, S., Lobschat, L., Rangaswamy, A., \& Skiera, B. (2010). The Impact of New Media on Customer Relationships. Journal of Service Research, 13, 311-330. https://doi.org/10.1177/1094670510375460

Huang, G. H., \& Korfiatis, N. (2015). Trying before Buying: The Moderating Role of Online Reviews in Trial Attitude Formation toward Mobile Applications. International Journal of Electronic Commerce, 19, 77-111. https://doi.org/10.1080/10864415.2015.1029359

Johnen, M., \& Schnittka, O. (2019). When Pushing Back Is Good: The Effectiveness of Brand Responses to Social Media Complaints. Journal of the Academy of Marketing 
Science, 47, 858-878. https://doi.org/10.1007/s11747-019-00661-x

Joško Brakus, J., Schmitt, B. H., \& Zhang, S. (2014). Experiential Product Attributes and Preferences for New Products: The Role of Processing Fluency. Journal of Business Research, 67, 2291-2298. https://doi.org/10.1016/j.jbusres.2014.06.017

Kelley, H. H., \& Michela, J. L. (1980). Attribution Theory and Research. Annual Review of Psychology, 31, 457-501. https://doi.org/10.1146/annurev.ps.31.020180.002325

Kim, P. H., Ferrin, D. L., Cooper, C. D., \& Dirks, K. T. (2004). Removing the Shadow of Suspicion: The Effects of Apology versus Denial for Repairing Competence-versus Integrity-Based Trust Violations. Journal of Applied Psychology, 89, 104. https://doi.org/10.1037/0021-9010.89.1.104

Kim, S. J., Wang, R. J. H., Maslowska, E., \& Malthouse, E. C. (2016). “Understanding a Fury in Your Words": The Effects of Posting and Viewing Electronic Negative Word-of-Mouth on Purchase Behaviors. Computers in Human Behavior, 54, 511-521. https://doi.org/10.1016/j.chb.2015.08.015

Lee, C. H., \& Cranage, D. A. (2014). Toward Understanding Consumer Processing of Negative Online Word-of-Mouth Communication: The Roles of Opinion Consensus and Organizational Response Strategies. Journal of Hospitality \& Tourism Research, 38, 330-360. https://doi.org/10.1177/1096348012451455

Lee, M., \& Youn, S. (2009). Electronic Word of Mouth (eWOM): How eWOM Platforms Influence Consumer Product Judgment. International Journal of Advertising, 28, 473-499. https://doi.org/10.2501/S0265048709200709

Lee, Y. L., \& Song, S. (2010). An Empirical Investigation of Electronic Word-of-Mouth: Informational Motive and Corporate Response Strategy. Computers in Human Behavior, 26, 1073-1080. https://doi.org/10.1016/j.chb.2010.03.009

Li, C. (2018). Tailoring Management Response to Negative Reviews: The Effectiveness of Accommodative versus Defensive Responses. Computers in Human Behavior, 84, 272-284. https://doi.org/10.1016/j.chb.2018.03.009

Li, C., Cui, G., \& Peng, L. (2017). The Signaling Effect of Management Response in Engaging Customers: A Study of the Hotel Industry. Tourism Management, 62, 42-53. https://doi.org/10.1016/j.tourman.2017.03.009

Ma, L., Sun, B., \& Kekre, S. (2015). The Squeaky Wheel Gets the Grease-An Empirical Analysis of Customer Voice and Firm Intervention on Twitter. Marketing Science, 34, 627-645. https://doi.org/10.1287/mksc.2015.0912

Malthouse, E. C. (2007). Mining for Trigger Events with Survival Analysis. Data Mining and Knowledge Discovery, 15, 383-402. https://doi.org/10.1007/s10618-007-0074-x

Marcus, A. A., \& Goodman, R. S. (1991). Victims and Shareholders: The Dilemmas of Presenting Corporate Policy during a Crisis. Academy of Management Journal, 34, 281-305. https://doi.org/10.2307/256443

Mauri, A. G., \& Minazzi, R. (2013). Web Reviews Influence on Expectations and Purchasing Intentions of Hotel Potential Customers. International Journal of Hospitality Management, 34, 99-107. https://doi.org/10.1016/j.ijhm.2013.02.012

Min, H., Lim, Y., \& Magnini, V. P. (2015). Factors Affecting Customer Satisfaction in Responses to Negative Online Hotel Reviews: The Impact of Empathy, Paraphrasing, and Speed. Cornell Hospitality Quarterly, 56, 223-231. https://doi.org/10.1177/1938965514560014

Proserpio, D., \& Zervas, G. (2017). Online Reputation Management: Estimating the Impact of Management Responses on Consumer Reviews. Marketing Science, 36, 645-665. https://doi.org/10.1287/mksc.2017.1043 
Purnawirawan, N., Eisend, M., De Pelsmacker, P., \& Dens, N. (2015). A Meta-analytic Investigation of the Role of Valence in Online Reviews. Journal of Interactive Marketing, 31, 17-27. https://doi.org/10.1016/j.intmar.2015.05.001

Robertson, T. S., \& Rossiter, J. R. (1974). Children and Commercial Persuasion: An Attribution Theory Analysis. Journal of Consumer Research, 1, 13-20.

https://doi.org/10.1086/208577

Rose, M., \& Blodgett, J. G. (2016). Should Hotels Respond to Negative Online Reviews? Cornell Hospitality Quarterly, 57, 396-410. https://doi.org/10.1177/1938965516632610

Schamari, J., \& Schaefers, T. (2015). Leaving the Home Turf: How Brands Can Use Webcare on Consumer-Generated Platforms to Increase Positive Consumer Engagement. Journal of Interactive Marketing, 30, 20-33.

https://doi.org/10.1016/j.intmar.2014.12.001

Sen, S., \& Lerman, D. (2007). Why Are You Telling Me This? An Examination into Negative Consumer Reviews on the Web. Journal of Interactive Marketing, 21, 76-94. https://doi.org/10.1002/dir.20090

Sheng, J. (2019). Being Active in Online Communications: Firm Responsiveness and Customer Engagement Behaviour. Journal of Interactive Marketing, 46, 40-51. https://doi.org/10.1016/j.intmar.2018.11.004

Sparks, B. A., So, K. K. F., \& BRADLEY, G. L. (2016). Responding to Negative Online Reviews: The Effects of Hotel Responses on Customer Inferences of Trust and Concern. Tourism Management, 53, 74-85. https://doi.org/10.1016/j.tourman.2015.09.011

Sreejesh, S., \& Anusree, M. R. (2016). The Impacts of Customers' Observed Severity and Agreement on Hotel Booking Intentions: Moderating Role of Webcare and Mediating Role of Trust in Negative Online Reviews. Tourism Review, 71, 77-89. https://doi.org/10.1108/TR-08-2015-0037

Tathagata, G., \& Amar, R. G. (2018). Gulping the Poison: How Webcare Attributes Reduce Damages to Brands Caused by Negative Reviews. Journal of Internet Commerce, 17, 216-254. https://doi.org/10.1080/15332861.2018.1463793

Tirunillai, S., \& Tellis, G. J. (2012). Does Chatter Really Matter? Dynamics of User-Generated Content and Stock Performance. Marketing Science, 31, 198-215. https://doi.org/10.1287/mksc.1110.0682

van Laer, T., de Ruyter, K., \& Cox, D. (2013). A Walk in Customers' Shoes: How Attentional Bias Modification Affects Ownership of Integrity-Violating Social Media Posts. Journal of Interactive Marketing, 27, 14-27. https://doi.org/10.1016/j.intmar.2012.09.002

van Noort, G., \& Willemsen, L. M. (2012). Online Damage Control: The Effects of Proactive versus Reactive Webcare Interventions in Consumer-Generated and Brand-Generated Platforms. Journal of Interactive Marketing, 26, 131-140. https://doi.org/10.1016/j.intmar.2011.07.001

Vermeulen, I. E., \& Seegers, D. (2009). Tried and Tested: The Impact of Online Hotel Reviews on Consumer Consideration. Tourism Management, 30, 123-127. https://doi.org/10.1016/j.tourman.2008.04.008

Wang, Y., \& Chaudhry, A. (2018). When and How Managers' Responses to Online Reviews Affect Subsequent Reviews. Journal of Marketing Research, 55, 163-177. https://doi.org/10.1509/jmr.15.0511

Wei, W., Miao, L., \& Huang, Z. (2013). Customer Engagement Behaviors and Hotel Responses. International Journal of Hospitality Management, 33, 316-330. https://doi.org/10.1016/j.ijhm.2012.10.002 
Weiner, B. (1979). A Theory of Motivation for Some Classroom Experiences. Journal of Educational Psychology, 71, 3.

Weitzl, W., \& Hutzinger, C. (2017). The Effects of Marketer- and Advocate-Initiated Online Service Recovery Responses on Silent Bystanders. Journal of Business Research, 80, 164-175. https://doi.org/10.1016/j.jbusres.2017.04.020

Weitzl, W., Hutzinger, C., \& Einwiller, S. (2018). An Empirical Study on How Webcare Mitigates Complainants' Failure Attributions and Negative Word-of-Mouth. Computers in Human Behavior, 89, 316-327. https://doi.org/10.1016/j.chb.2018.07.012

Xie, K. L., Zhang, Z., \& Zhang, Z. (2014). The Business Value of Online Consumer Reviews and Management Response to Hotel Performance. International Journal of Hospitality Management, 43, 1-12. https://doi.org/10.1016/j.ijhm.2014.07.007

Yan, L., \& Wang, X. (2018). Why Posters Contribute Different Content in Their Positive Online Reviews: A Social Information-Processing Perspective. Computers in Human Behavior, 82, 199-216. https://doi.org/10.1016/j.chb.2018.01.009

Zhu, F. (2010). Impact of Online Consumer Reviews on Sales: The Moderating Role of Product and Consumer Characteristics. Journal of Marketing, 74, 133-148.

https://doi.org/10.1509/jm.74.2.133 